\title{
Preparation and Production of High Grade Sulfonic Acid
}

\author{
Abbas Hadi. Al-Shukrawi ${ }^{1}$, Wedad H. Al-Dahhan ${ }^{2}$, Ammal Esmaeel Ibrahim ${ }^{3}$ \\ ${ }^{1,2,3}$ Chemistry Department, Al-Nahrain University, Baghdad-Iraq
}

\begin{abstract}
Sulfonic acid was prepared in laboratory by mixing Linear Alkyl Benzene, LAB ( which produced by the Arabic Chemicals for Detergents at Beige / Iraq ) with fumic Sulfuric acid at 55-60 C for one minute residence time to know and to verify the practical conditions and requirements to be applied for mass production process flow sheet of high grade sulfonic acid production every pass which stimulates the construction of some fruitful plants locally. Samples of the prepared sulfonic acid were analyzed using Foot PrintIR Spectrometry showing that functional groups sites of the prepared compound are in coincidence with that of the standard Linear Alkyl benzene Sulfonic acid according to Colthup's tables for spectroscopic analytical data of standard compounds. The reaction is reliable, and almost of quantitative recovery within one minute residence time but it is highly exothermic; therefore a high efficient heat exchanger recommended to supply urgent cooling and appropriate materials selection should be considered for the construction of plant units, such as its resistance to corrosion as well as their homogeneity characteristics for thermal flow to avoid the production of side products which result in the production of low quality product; hence an auxiliary software should be constructed to control the process for high quality product insurance.
\end{abstract}

Keywords: Sulfonic acid was prepared in laboratory by mixing Linear Alkyl Benzene

\section{Introduction}

Soaps and synthetic detergents are classified as" fine chemicals ", they were known during the past decades. Their growing use was erupted during the first and second World Wars due to increasingly consumption of animal fats and vegetable oils such as coconut oil, olive oil, sunflower oil and castor oil for human feed that leads to the development of industrial researches since 1940 to prepare sulfonic acid the basic raw material for synthetic detergent industry via alkyl benzene sulfonation with oleum. Therefore production of alkyl benzene is considered the front base for construction and development of detergents industry all over the World. Sulfonic acid mass production can be verified easily using petroleum cuts such as kerosene and benzene that initially produce alkyl benzenes which sulfonated by $\mathrm{SO}_{3}$ gas or oleum to sulfonic acid, many well known companies were going in a race to produce linear alkyl sulfonic acid, $L A B$ due to the increasing lack of detergents and to magnify petroleum investments. The global World production of sulfonic acid was 3,356 million tons more than59\% produced at Asia and Middle East Countries( Table-1)[1].
Table 1: Global Production of Sulfonic Acid for 2007*

\begin{tabular}{|c|c|c|}
\hline & Site of Production & $\%$ \\
\hline 1 & Asia & 47 \\
\hline 2 & West Europe & 14 \\
\hline 3 & Northern America & 13 \\
\hline 4 & Middle East & 12 \\
\hline 5 & Latin America & 10 \\
\hline 6 & Eastern Europe & 2 \\
\hline 7 & Africa & 2 \\
\hline
\end{tabular}

*Global production 3.356 million tons.

After the second World War synthetic alkyl naphthalene 's detergents of short carbon chains were prepared by reaction of propyl or butyl alcohols with naphthalene,then sulfonated to produce the detergents, among those was the well known Nekal of powerful foam, high wetting and fast humidifying, for such properties it is still used in textile industry. During 1920-1930 long chain alcohol sodium sulfonates and branched alkyl benzene sodium sulfonates,BABSS were produced at United States of America. Tide the novel detergent was a mixture of both of them as well as some additives. Shampoo, Teepol,Igepon T, and Mesolate were produced by secondary long chain alcohols produced either by Zeigler Synthesis ( produce $50 \%$ of detergents ) or petroleum cuts[ 2-7 ]. Branched Alkyl Benzene was prepared by the reaction of propylene- tetramer and benzene as in the following equations (1\&2):

$$
\begin{aligned}
4 \mathrm{CH}_{2}=\mathrm{CH}-\mathrm{CH}_{3} & \stackrel{\mathrm{H}_{3} \mathrm{PO}_{4}}{\longrightarrow} \mathrm{CH}_{3}\left(\mathrm{CH}_{2}\right){ }_{10} \mathrm{CH}_{3} \ldots 1 \\
\text { 1-Propene } & \text { Propylene Tetramer }
\end{aligned}
$$

\section{Propylene Tetramer}

The branched alkyl benzene treated with oleum yielding Tetra Propylene Benzene Sulfonic Acid, TPBS, then neutralized with sodium hydroxide forming the branched alkyl benzene sodium sulfonate BABSS, of environmental draw bags due to its long biological degradation time, foam stability upon the surfaces of rivers and lakes assists growth of algae colonies clusters and blockage of plant drainages, for such reasons linear alkyl benzene sulfonic acid, LAS, was produced by reaction of linear alkyl benzene, $\mathrm{LAB}$ with $\mathrm{SO}_{3}$ gas or oleum ( eq.-3 ).LAB is synthesized by alkylation of benzene and normal olefins produced brought by petroleum cuts.

\section{Volume 5 Issue 5, May 2016}


International Journal of Science and Research (IJSR)

ISSN (Online): 2319-7064

Index Copernicus Value (2013): 6.14 | Impact Factor (2015): 6.391

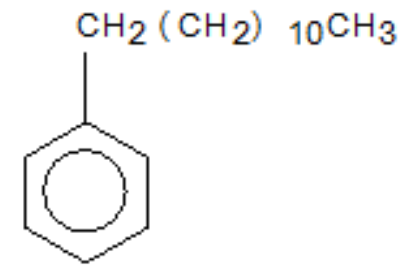

Linear Alkyl Benzene ( $\mathrm{LAB}$ )

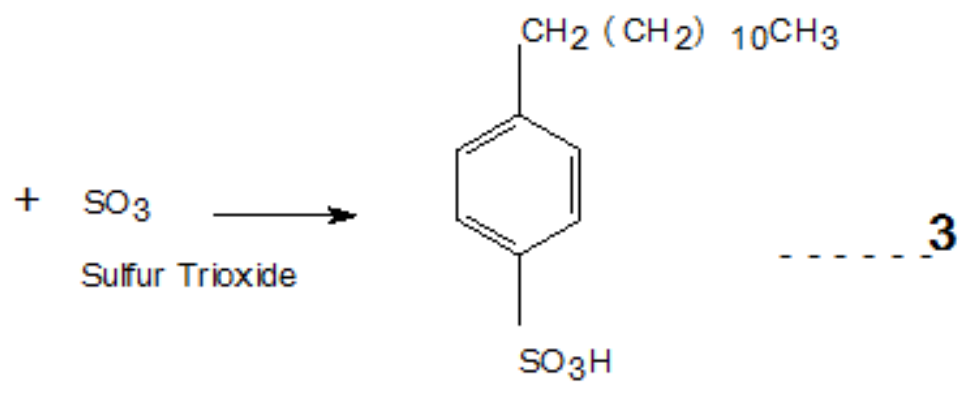

n-Dodycle Benzene Sulfonic Acid

( LAS)

Hydrofluoric acid was used as alkylation catalyst since 1960( UOP-process ), such process has many problems related to high corrosive ability of the catalyst which restrict materials selection to the valuable inconieal, monieal and histalloy-c for construction of plant units, as well as its harm for human beings and environment [ 8-12 ], soon a new modified process using a solid fixed bed catalyst ( DETAL) was developed as a real revolution in synthetic detergents industry due to the ease of plants construction using this process. The properties of sulfonic acid differs due to petroleum cuts raw materials, table-2 depicts the properties of Iraqi sulfonic acid for its straight chain alkyl radicals.

Table 2: Guaranteed specifications of Iraqi- LAB

\begin{tabular}{|c|c|c|}
\hline Property & Value & Test Method \\
\hline $\begin{array}{c}\text { Molecular Weight } \\
\text { Normal Alkyl Benzene Wt. } \\
\text { pct. }\end{array}$ & $240 \pm 2$ & UOP-673 \\
\hline 2-Phenylalkane Wt. pct. & $20.0 \mathrm{Max}$. & UOP-698 \\
\hline Bromine Color & $40 \mathrm{Max}$. & ASTM D-1492 \\
\hline Saybolt Color & $29 \mathrm{~min}$. & ASTM D-156 \\
\hline Doctor Test & Negative & UOP-41 \\
\hline Paraffin Content,Wt.pct. & $0.5 \mathrm{Max}$. & UOP-621 \\
\hline $\begin{array}{c}\text { Biodegradability of Sodium } \\
\text { Alkyl Benzene Sulfonate, } \\
\text { Wt. pct. }\end{array}$ & 90 Minute & ASTM D-2667 \\
\hline $\begin{array}{c}\text { Completeness of } \\
\text { sulfonation,Wt.pct. }\end{array}$ & 98 & UOP-429 \\
\hline
\end{tabular}

Raw materials for linear alkyl benzene production are benzene and kerosene that comes out of fractionation distillation towers along temperature range 190-250 $\mathrm{C}^{\circ}$ ( $20 \%$ of kerosene production ) which contains normal paraffins of 11-18 carbon atoms suitable for detergents industry. Kerosene is initially thermally treated to expel polar compounds such as water which deactivate the molecular sieves that separate normal paraffins out of branched ones, then normal paraffins converted to $\alpha$ - olefins by dehydrogenation process [ 3-12 ]. Olefins are found in petroleum and natural gas by small proportions due to their chemical reactivity therefore it could be produced by heavy oils cracking processes.

\subsection{Catalytic Cracking}

Process converts heavy oil cuts of petroleum to paraffins, cyclo paraffins, naphthenes, and aromatic compounds using Fluid bed Cracking Catalyst, FCC, and Thermal Cracking Catalyst, TCC, such as Zeolites, Aluminum Silicates, Chromium Dioxide and Manganese Oxide. Cracking occurred at $400-500 \mathrm{C}^{\circ}$. Addition of Platinum and Lanthanides to catalyst increases its activity by reducing charring phenomena to minimum due to conversion Carbon and Carbon Monoxide to Carbon Dioxide

\subsection{Hydro-Cracking}

Process converts Liquefied Petroleum Gas, LPG, with hydrogen to isobutylene, gasoline and naphtha using zeolites, Al-silicates, $\mathrm{Pt}, \mathrm{Pd}$, and Co-Mo catalysts at temperatures 220$450 \mathrm{C}^{\circ}$ / 80-200 bar. The process consumes 300-500 $\mathrm{m}^{3}$ of Hydrogen gas / 1 ton heavy oil. This process is too costly and too dangerous to be used in a petroleum refinery.

\subsection{Thermal Cracking}

Practical cracking process occurred at $400-500 \mathrm{C}^{\circ}$, it is carried out by free radical mechanism within 0.5 second, produces olefins and aromatic compounds needed for linear alkyl benzene production according to Fridel-Crafts synthesis (eq4) $[3-12]$.

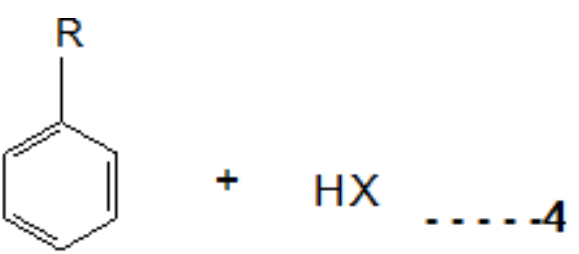

Hydrogene

Halide 


\section{International Journal of Science and Research (IJSR) \\ ISSN (Online): 2319-7064}

Index Copernicus Value (2013): 6.14 | Impact Factor (2015): 6.391

Sulfonic acid is called " the jewels of the crown " for its vast uses, e.g. an active ingredient in synthetic detergents, an additive to white and blue dyes for plastic, rubber and synthetic fibers, emulsifying and wetting agent, admixture with other soap types to improve their specifications, LAS used with cationic exchangers for chromatographic analysis (HPLC) [13] and as anti scaling agent in steam boilers[14]. The physical properties of LAS are shown in (Table-3)as well ease of bio degradation, efficient, economic, high thermal and light stability(up to $350 \mathrm{C}^{\circ}$ ). It is clear that novel companies such as UOP, DETAL, Petresa, Tecsaco, Exxon-Kellogy and Stone\&Webster design and construct detergent plants according to the available raw materials and product specifications satisfying people needs of area under plan.

Table 3: Physical Properties of Linear Alkyl Benzene Sulfonate

\begin{tabular}{|c|l|l|}
\hline 1 & Physical State & Brown Liquid \\
\hline 2 & Melting Point & $10 \mathrm{C}^{\circ}$ \\
\hline 3 & Boiling Point & $315 \mathrm{C}^{\circ}$ \\
\hline 4 & Specific Gravity & 1.2 \\
\hline 5 & Molecular Weight & $346.49 \mathrm{gm}$ \\
\hline 6 & Solubility & Partially Soluble \\
\hline 7 & NEPA Ratings & $\begin{array}{l}\text { Health } 2 \text {, Flammability 0, } \\
\text { Reactivity 0 }\end{array}$ \\
\hline 8 & Toxicity & Oral rat $\mathrm{LD}_{50}=650 \mathrm{mg} / \mathrm{kg}$ \\
\hline 9 & Flash Point & $149 \mathrm{C}^{\circ}$ \\
\hline 10 & Stability & $\begin{array}{l}\text { Stable under ordinary } \\
\text { conditions }\end{array}$ \\
\hline 11 & Active Matter & $96 \%$ \\
\hline 12 & Free Oil & $1.5 \%$ Max. \\
\hline 13 & Water & $1 \%$ \\
\hline
\end{tabular}

Industrial development authorities consider that the availability of raw materials such as sulfur and petroleum are basic encouraging factors for construction and proliferation of different industries, therefore the aim of this research is to enhance construction some detergent plants locally on basis of optimized annual production capacity ( $70000-100000$ tons/year ) estimated upon the global amounts of imported detergents as well as the increasing future demands. Mass production of sulfonic acid using Thin Film Tube Reactor, TFTR controlled by digital computers is a typical, efficient, reliable and environmentally safe process using heterogeneous phase reaction of $\mathrm{SO}_{3}$ gas and linear alkyl benzene over inert surface media.

Our aim in this project is to determine the conditions responsible for the production of low grades sulfonic acid with variable properties for every pass which produced by the locally constructed domestic sulfonic acid plants plants.

\section{Procedure}

Alkyl benzene is sulfonated in laboratory by mixing LAB with fumic sulfuric acid ( $96 \%$ ) i,e it contains 3-4 \% $\mathrm{SO}_{3}$ gas in equilibrium with the acid (10 milliliters LAB with 50 milliliters fumic sulfuric acid) is mixed into a reaction vessel for different time intervals using a variable speed mechanical stirrer, at the end of every time interval samples were withdrawn out of the reaction vessel using a glass dropper for chemical and physical analysis.. The reaction vessel is a round bottom flask ( $500 \mathrm{ml}$. ) made of Pyrex glass with three neck ports, the middle port used for mechanical stirrer, the second for a quick fit thermometer and the third one for reactants addition and sampling, the reaction vessel containing reactants is immersed into water of thermostatic circulator at fixed temperature degree, the procedure could be summarized as follows :

\subsection{Determination of Residence Time}

Experiments to determine the best residence time of the reaction $0.5,1.0,2.0,3.0,5.0 .10 .0,15.0$ and 30 minutes( fig.$1)$

\subsection{Determination of Reaction Temperature}

Experiments to determine the best reaction temperature 50, 55, 60 and $65 \mathrm{C}^{\mathrm{o}}$ ( Table- 4 ).

\subsection{Analysis}

Laboratory experiments were analyzed by neutralization of sulfuric acid during the course of each experiment using Potentiograph E- 536 and Dosimat E-536 ( $\pm 0.01 \mathrm{ml}$. ).

\subsection{FTIR- Spectroscopy}

The final samples were analyzed using Foot Print IRSpectrometry.

\section{Results and Discussion}

Sulfonic acid was prepared in laboratory using linear alkyl benzene produced by the Arab Chemicals Company for Detergents at Beige / Iraq proved that 3 minute is the best residence time for sulfonation reaction as seen in fig.-1( 98.5 $\%$ recovery).

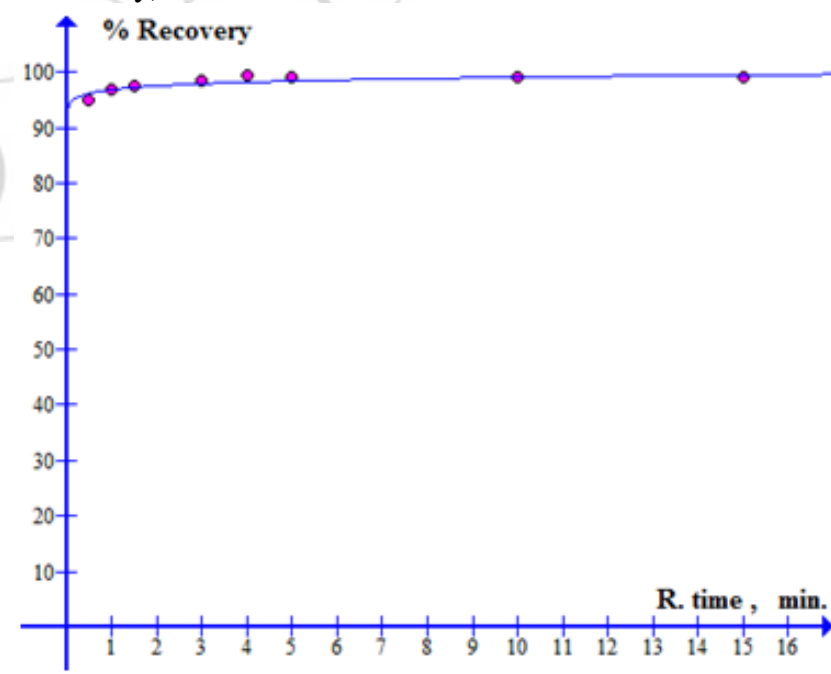

Figure 1: Residence Time of Sulfonation Reaction

Sulfonation is a highly exothermic reversible reaction as seen in eq.-3 ( $\Delta \mathrm{G}=-40 \mathrm{Kcal} . /$ mole $)$ confirms the essential role of heat control ought to be applied verified using efficient heat exchangers to maintain reaction temperature within 50$60 \mathrm{C}^{\circ}$ in order to avoid LAB over sulfonation to di- sulfone, 


\section{International Journal of Science and Research (IJSR) \\ ISSN (Online): 2319-7064}

Index Copernicus Value (2013): 6.14 | Impact Factor (2015): 6.391

sulfone and anhydrous sulfone eqs. ( $5 \& 6$ ) which add bad properties to LAS, then to the produced detergents, Disulfone could be converted to LAS by addition of equivalent amounts of LAB, more over sulfone and anhydrous sulfone hydrated to LAS during reaction course.<smiles></smiles>

Alkyl Benzene

Oleum

Di-Sulfone

Acid

Sulfonic Acid

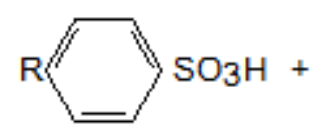

Alkyl Benzene

Sulfonic Acid

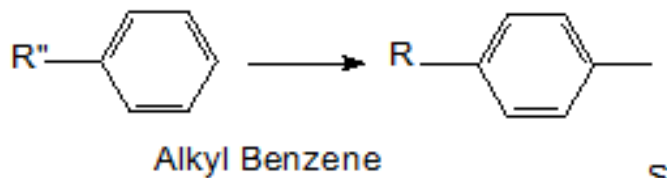

Sulfone

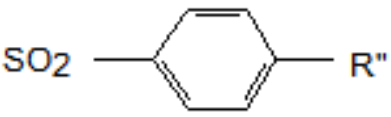

$--6$

$+\mathrm{H}_{2} \mathrm{O}$

Water

Table- 4 illustrates the vital role degree of temperature for sulfonation reactions, at $50 \mathrm{C}^{\circ}$ lower yield of product was attained, when as at $60-65 \mathrm{C}^{\circ} \mathrm{LAS}$ product is contaminated with the pre mentioned by products noticed by the dark brown color of the prepared LAS, but at 55-60 $\mathrm{C}^{\circ}$ is considered the best reaction temperature because of high purity LAS prepared ( light brown color, resemble to pure honey color ), this narrow temperature range is because of the sensitivity of sulfonation reaction for it is highly exothermic reaction ; therefore such conditions necessitates the role of the auxiliary equipment such as efficient heat exchanger systems recommended to supply urgent cooling and appropriate materials selection should be considered for the construction of plant units, such as their resistance to corrosion as well as their homogeneity characteristics for dynamic homogenous thermal flow to avoid the production of unwanted side products by locally heat concentration points inside the tube reactor which result in the production of low quality LAS product ; moreover an auxiliary software should be constructed to control the process for reliable high quality product insurance for every pass. The locally constructed domestic sulfonation plants did not aware for such control auxiliary equipment on behalves of cost investments rather than product quality.
Table 4: Effect of Temperature on LAS Properties*

\begin{tabular}{|c|c|c|}
\hline Temp. Deg. C $^{\mathbf{o}}$ & Color & \%Yield \\
\hline 50 & Light Brown & 90 \\
\hline 55 & Light Brown & 98 \\
\hline 60 & Light Brown & 98 \\
\hline 65 & Dark Brown & 98 \\
\hline
\end{tabular}

*Residence time of the reaction is 1 minute

Fig.-2 showing the FTIR analytical profile of the prepared sulfonic acid by Foot Print IR-Spectrometry reflects excellent coincidence of functional groups sites according to LAS standard compound on basis of Culthup's tables for standard chemicals [15-16 ], the double bonds of benzene ring for the compound appeared at $1598.9,1450 \mathrm{Cm}^{-1}$ where as for LAS standard compound appear at 1600, $1580 \& 1450 \mathrm{Cm}^{-1}$ respectively, $\gamma \mathrm{C}-\mathrm{H}$ of benzene ring appeared at $2858.9 \mathrm{Cm}^{-1}$ but for LAS appears at $3000 \mathrm{Cm}^{-1}$, meanwhile $\mathrm{C}-\mathrm{H}$ rock at ( $\left.665.5 \mathrm{Cm}^{-1}\right) \& \mathrm{C}^{-} \mathrm{C}_{\text {stretch }}$ at $\left(835.1 \mathrm{Cm}^{-1}\right)$ when as for LAS standard appear at $600-900 \mathrm{Cm}^{-1}, 800-1200 \mathrm{Cm}^{-1}$ respectively, proving that the prepared compound is Linear Alkyl Benzene Sulfonic Acid. 


\section{International Journal of Science and Research (IJSR) \\ ISSN (Online): 2319-7064}

Index Copernicus Value (2013): 6.14 | Impact Factor (2015): 6.391

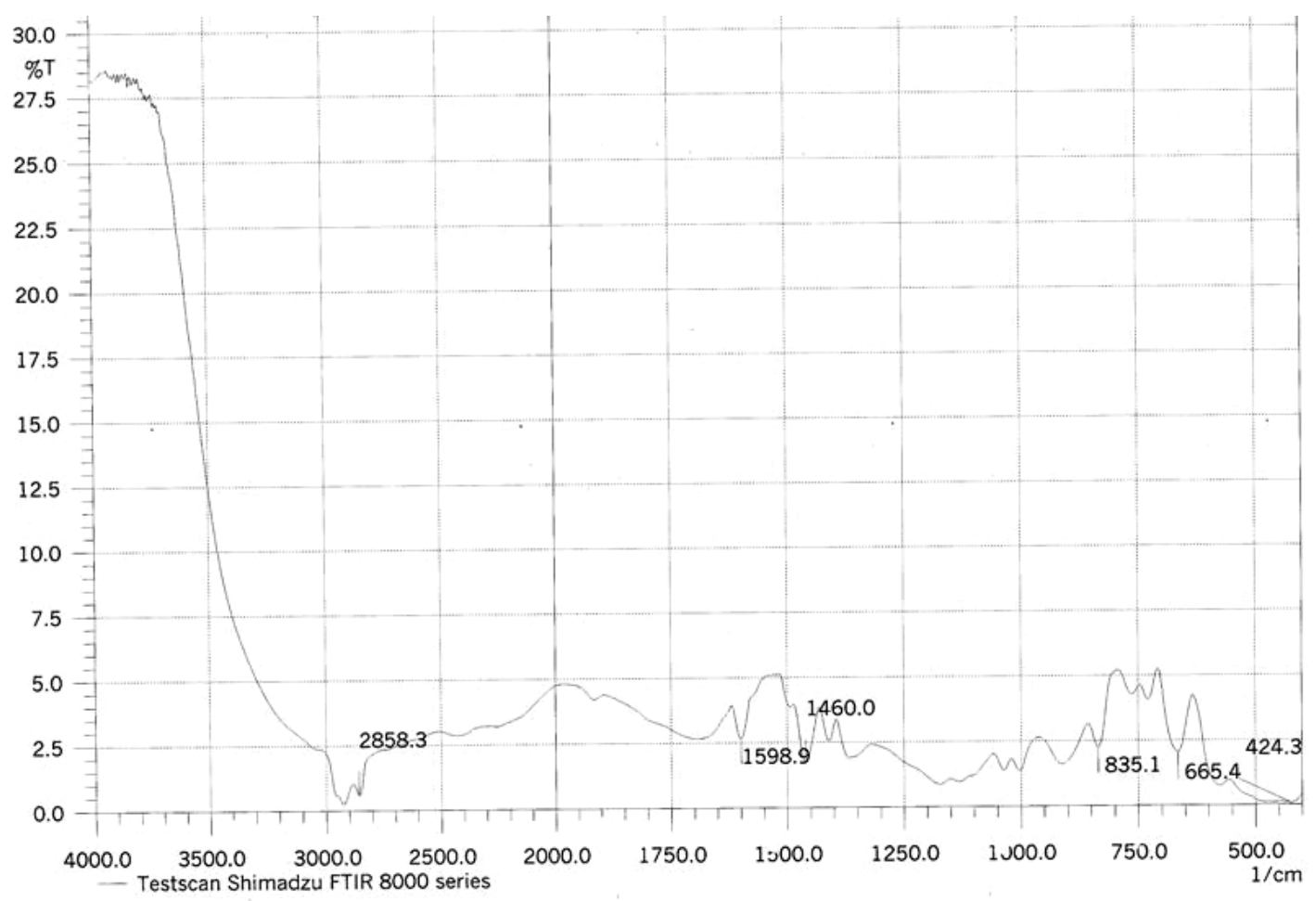

Figure 2: FTIR - Spectrum for the Prepared Sulfonic Acid.

Iraqi - LAB has many advantages( over the previously mentioned, $\mathrm{BAB}$ ) due to straight Carbon chain of its alkyl group, therefore it is easily bio degraded by bacteria within 90 minutes (Table-2) hence it is safe with regards to environmental considerations. The chemical structure of alkyl benzene affects the properties of the prepared detergent such as dissolution ability and foaming power that increases as branching of the alkyl group increases meanwhile the time of bio degradability increases too approaching unacceptable values so recent researches trying to approach a hygiene alkyl benzene of most practical properties using new processes depend upon Fisher Tropsch synthesis [8, $17-20]$.

Table-5 explains the wide spread of newly constructed detergent plants in our area [ 21-30 ] especially for Arabian Gulf countries who were participating in planning and construction of the Arab Chemical Detergents Company a Beige / Iraq which work now at $2.2 \%$ of its annual capacity.

Table 5: Some LAB Companies in our Area

\begin{tabular}{|c|c|c|c|c|}
\hline & Company & Site & $\begin{array}{c}\text { LAB } \\
\text { Tons/year }\end{array}$ & $\begin{array}{c}\text { Date of } \\
\text { Operation }\end{array}$ \\
\hline $\mathbf{1}$ & $\begin{array}{c}\text { Saief Co. Ltd. (Qatar } \\
\text { petroleum Co. ) }\end{array}$ & Qatar & $100000^{\#}$ & 2006 \\
\hline $\mathbf{2}$ & $\begin{array}{c}\text { Al-Faraby ( of Al- } \\
\text { Ragihy group) }\end{array}$ & $\begin{array}{c}\text { Saudia Arabia } \\
\text { Kingdom ( Al- } \\
\text { Gubail ) }\end{array}$ & 70000 & 2006 \\
\hline $\mathbf{3}$ & $\begin{array}{c}\text { Group of Indian } \\
\text { Companies for New } \\
\text { Detergents }\end{array}$ & $\begin{array}{c}\text { India ( New } \\
\text { Delhi ) }\end{array}$ & 80000 & 1986 \\
\hline $\mathbf{4}$ & $\begin{array}{c}\text { Arab for Chemical } \\
\text { Detergents Co. }\end{array}$ & $\begin{array}{c}\text { Republic of } \\
\text { Iraq ( Beige ) }\end{array}$ & 1091 & 1980 \\
\hline
\end{tabular}

\# Plus 3600 tons HAB ( highly alkylated alkyl benzene ) used for LUB- oils. + Three plants.

*Of 50000 tones/year ( annual capacity ).

\section{Results and Suggestions}

The aim of this research is to verify the requirements of Beige-LAB sulfonation process in order to encourage construction some plants of optimized annual capacities ( 70000-100000 tons / year) estimated on basis of our needs for detergents. Such plants increase work chances for our people, establish better market to our pure sulfur and petroleum resources capable to increases investments 7-8 folds for the raw materials consumed by detergent industry.

\section{References}

[1] (internet) www.chemsystems.com/ 1- Nexants, Inc. 2009

[2] George T. Austin " Shreve's Chemical Process Industries", $5^{\text {th }}$. Edition, McGraw Hill International Editions, New York, 1984.

[3] Mohammed Farhat Ali, Bassam El Ali \& Games G.Speight " Industrial Chemical Organic Chemicals ", McGraw Hill, New York, 2005.

[4] Kent J. Riegel's \&Van Notrand Reinhold, " Handbook of Industrial Chemistry " New York 1997.

[5] Davidson,A.S. \& B. Milwidsky " Synthetic Detergents ", Scientific and Technical Burnt Mill, Harlow, England, 1987. Smulders E. " Laundry Detergents ", Wiely - VCH, Verlag - Germany 2002.

[6] M.M.Chakrabraty " Chemistry of Oils and Fats ", Allied Publication Ltd., New Delhi, 2003.

[7] Klaus Weissermsl and Hans-Jŭrgan ( Industrial Organic Chemistry ) $3^{\text {rd }}$ revised Ed., VCH, A Wiley Co. 1997.

[8] U. S. Patent No. 3,484,498.

[9] U. S. Patent No. 6,111,158.

[10] U. S. Patent No. 6,187, 158.

[11] Patent LASS No.6436154 ( 2002 )

[12] S.D.Fazio, J.B. Growthen and R.A. Hertwhich "Chromatographia ", Vol.18, No 4, Viewing Verlag, 


\section{International Journal of Science and Research (IJSR) \\ ISSN (Online): 2319-7064}

Index Copernicus Value (2013): 6.14 | Impact Factor (2015): 6.391

April 1984. pp-216-220

[13] Halverson,etal (Use of Dodecyl Benzene Sulfonic Acid or Salt as Scale inhibiter). (internet).

[14] Robert L.Pecsok, L.Donald Shields, Thomas C.Arins, " Modern Methods of -15

[15] Chemical Analysis ", John Wiley \&Sons, NewYork 1987.

[16] Culthups, J. Opt. Soc. Am. 40, 397, (1950).

[17] LAB New Developments, Kaschi Chemicals, LAB for Detergent Production.

[18] Science, Direct Applied Catalyst Production of LAB.( internet ).

[19] Search Enterprises Inc. / Sasol Co. / Sicily / Italy ( internet).

[20] " Applied Catalyst " A, General Vol. 221, Issues 1-2 (30 Nov. 2001 ) PP. PP 295- 301.

[21] Linear Alkyl Benzene Sulfonic Acid,file A/1/HTM19/04/1425.

[22] Kiwi Web, Chemistry \& New Zeland,CH:\ Synth. Det. History htm.

[23] Fine Chemicals (Soap and Detergents), file A/5/HTM $-19 / 04 / 1425$.

[24] Linear Alkyl Benzene Sulfonic Acid,file A/1/HTM19/04/1425.

[25] Linear Alkyl Benzene History, file A/2/HTM- 19-041425.

[26] Linear Alkyl Benzene Preparation and Application, Petresa 7/06/2004. 27- Hand Book of Detergent, part F, Production, Vol. 142 by Vri Zolles and Paul Sosis.

[27] Qatar Petroleum, LAB, Inaugurated, htm.

[28] LABSA, htm.

[29] Primary Information Surfactant,21 Murugappan St., Suramy Nager Ext.2,Ulagram,Chenia - 600091, India

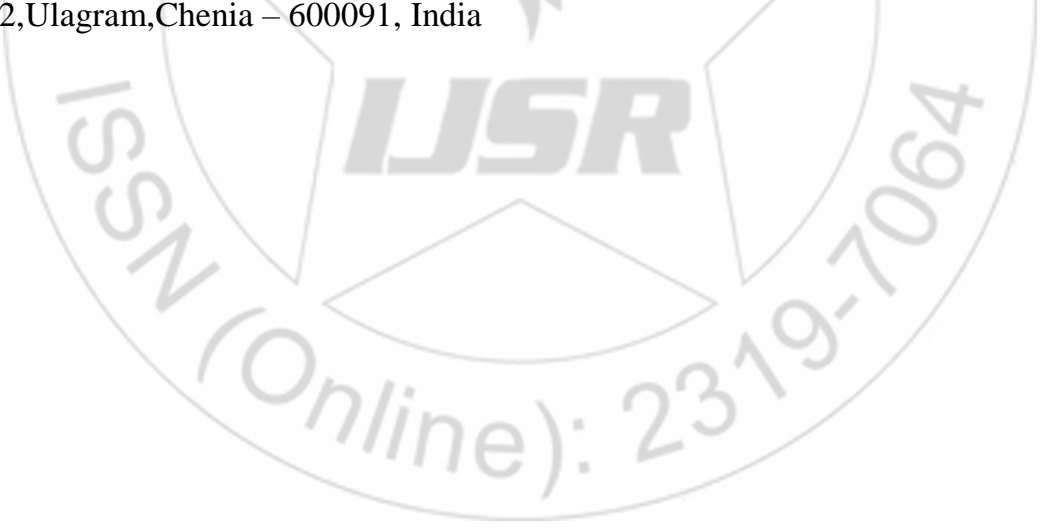

